\title{
SCENARIOS OF LATVIAN RURAL SCHOOLS IN THE FUTURE PERSPECTIVE
}

\section{Latvijas lauku skolu scenāriji nākotnes perspektīvā}

\author{
Anna Laizāne \\ Latvia University of Agriculture, Latvia \\ E-mail: anna_laizane@inbox.lv
}

\begin{abstract}
In the frameworks of the research on Latvian rural schools' educational environment there was carried out the forming experiment - cross-school mentoring in the organization form of five seminars that gathered 111 experts who represented educational sphere of two Latvian regions - Zemgale and Latgale. The aims of the article are 1) to give substantiation of the concept vision; 2) to describe the results of the cross-school mentoring seminars in the connection with: a) predictions of the future scenarios of sustainable development of rural schools and comparison of the results of future scenarios of 2004 with future scenarios of 2011 of sustainable development of rural schools and b) the influencing indicators of prestige and success of rural schools. The predictions of the future of scenarios of sustainable development reveal that there is an optimistic, pessimistic and realistic development and there are influencing factors of prestige of rural schools that are divided into two main groups: 1) representing factors of contexts (components) of school environment; 2) indicators of specificity of educational environment as prestige influencing factors.
\end{abstract}

Keywords: influencing factors of prestige of rural schools, optimistic, pessimistic and realistic scenarios of future development of rural schools, visions.

\section{Introduction}

The life of any person goes up and down all the time, not knowing where it leads and what it will bring. The nature of changes that enters our lives are of positive, neutral or negative nature, that makes us plan, decide and solve problems etc. Our life consists of stages so that we see our future and plan activities in it. The same mechanism takes place in the life of any organization, including rural schools, where great role is played by human resources, their ideas, initiative and wish to make their organization better and targeted at the fulfillment of mission and aims of it. Planning is the key element in the sustainable process of any organisation that makes functioning transparent and flexible for everyone.

The aims of the article are 1) to give substantiation of the concept vision;2) to describe the results of the cross-school mentoring seminars in the connection with: a) predictions of the future scenarios of sustainable development of rural schools and comparison of the results of future scenarios of 2004 with future scenarios of 2011 of sustainable development of rural schools and b) the influencing indicators of prestige and success of rural schools. The methods are: observations, the content analysis of documents, pedagogical experiment in the process of cross-school mentoring, the method of future scenarios (according to Walt Disney model after O'Connor J., Seymour J., 1994) and brainstorm method. 
SOCIETY, INTEGRATION, EDUCATION. Proceedings of the International Scientifical Conference May 25th-26th, 2012, Volume I, Rēzeknes Augstskola, RA Izdevniecība, 2012,

pp. $107-116$

With the support of the European Social Fund project "Support of Doctoral Studies at the Latvia University of Agriculture" it was possible to carry out the forming experiment - cross-school mentoring in the organization form of seminars in Zemgale and Latgale regions (October, November, 2011) in five rural schools Jaunsilava Basic School, Valle Secondary School, Riebinu Secondary School, Skaistkalnes Secondary School and Anna Brigadere Basic School, gathering 111 experts. The aims of cross-school mentoring seminars were to approbate the crossschool mentoring for promotion of exchange of experience of rural schools in the experimental way, to facilitate the search of creative, innovative ideas for selfdevelopment and growth of organization as well as to popularize author's research in the context of problems of rural schools.

\section{Discussion}

Before revealing the results of cross-school mentoring seminars, it is very significant to substantiate the concept vision because scenarios of future development of any organization are formed by visions.

To start with, the author of the article would like to emphasize the concept vision. According to $\mathrm{Ph}$. A. Wood (Wood, 2005) the word vision has come into prominence, although the concept of what is expressed is very old. It is the emotive aspects of the world, as well as its meaning that have made it so popular. Vision is top management's expression of what the organisation is striving to become, and incorporates both the critical values of the organization (including rural schools). A vision is semi-permanent. It is likely to outlast any strategic plan that may be prepared, but will not last forever. It includes a description of the nature of the organisation's business as it is intended to be at the same time in the future. First the question „What is my business?" should be asked. A second question is even more important „What should my business be?" Typically the vision embraces a view not only of the evolution of the organisation, but also of the industry, and the unique position the organisation is intending to fill. The values of the organisation are important component of vision, and the typical vision statement will have some mention of how the organisation will conduct itself in relations to customers, employees, suppliers and the community. The vision can be used as a motivation agent to help managers and other employees to see the opportunities and to stretch beyond the short term.

The online book Strategic Leadership and Decision Making the section Strategic Vision (National Defence University, s.a) points out that formulating the vision is only the first step; implementing the vision is much harder, but must follow if the vision is going to have any effect on the organization. The three critical tasks of the strategic leader are formulating the vision, communicating it, and implementing it. Some organizations think that developing the vision is all that is necessary. If they have not planned for implementing that vision, development of the vision has been wasted effort. Even worse, a stated vision which is not implemented may have adverse effects within the organization because it initially 
SOCIETY, INTEGRATION, EDUCATION. Proceedings of the International Scientifical Conference May 25th-26th, 2012, Volume I, Rēzeknes Augstskola, RA Izdevniecība, 2012,

creates expectations that lead to cynicism when those expectations are not met. Before implementing the vision, the leader needs to communicate the vision to all the organization's stakeholders, particularly those inside the organization. The vision needs to be well articulated so that it can be easily understood. And, if the vision is to inspire enthusiasm and encourage commitment, it must be communicated to all the members of the organization.

Rural school is also an organization that has got its specific tasks to be carried out that are mostly connected with education and upbringing of children as well as youngsters, adults and the audience who is interested in lifelong process of education. Online Business Dictionary defines term organization as a social unit of people, systematically structured and managed to meet a need or to pursue collective goals on a continuing basis. All organizations have a management structure that determines relationships between functions and positions, and subdivides and delegates roles, responsibilities, and authority to carry out defined tasks. Organizations (including rural schools) are open systems in that they affect and are affected by the environment beyond their boundaries.

During scientifically practical cross-school mentoring seminars The Fluctuation of Educational Environment of Rural Schools in Latvia and Abroad in the 21st Century experts had to predict and present rural schools' future development visions and define the influencing indicators of prestige and success of rural schools nowadays.

First of all, the experts foresaw three scenarios of the sustainable development of rural schools - optimistic, pessimistic and realistic. According to the Walt Disney model (see Figure1) there is the correspondence of environment of human activity with the aims of visions that provides the appropriate state of mind as well as influences thinking of experts and content of it (after O'Connor, Seymour, 1994).

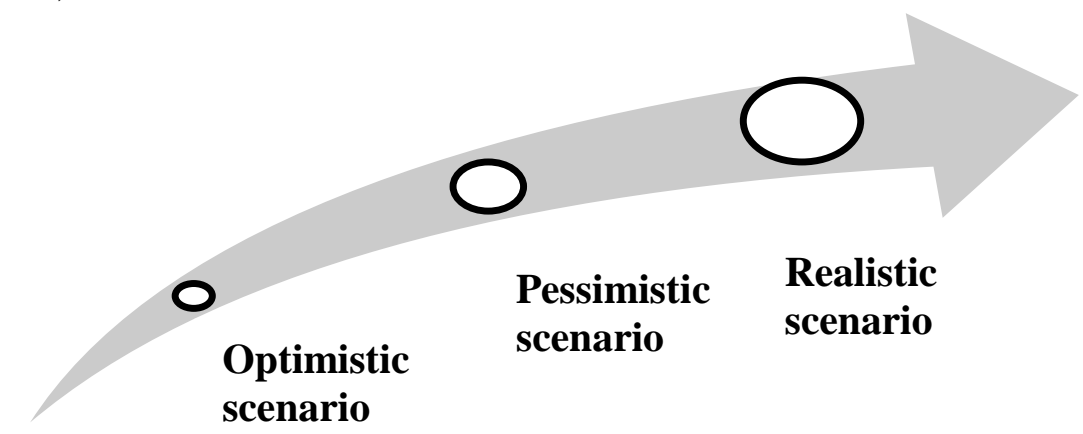

Figure 1. The Scenarios of Future Development of Rural Schools

(Authors' construction)

The brainstorm method was used in the work with experts that allowed them to produce many interesting ideas without discussion and unnecessary comments in the time of one hour. The brainstorming method is very effective for generating 
SOCIETY, INTEGRATION, EDUCATION. Proceedings of the International Scientifical Conference May 25th-26th, 2012, Volume I, Rēzeknes Augstskola, RA Izdevniecība, 2012,

interesting and extraordinary ideas. This method allows encouraging and perfecting each other, noticing partnership and equality principles. The representatives of rural schools made presentations and discussed all future scenarios of rural schools. The description of arranging environment of future visions of rural schools is the following:

- The brightly, neatly arranged room was prepared for the optimistic scenario of future of rural schools. There were lots of indoor plants. The arrangement of working places was appropriate to requirements of discussible, cooperative methods (desks were put in the form of horseshoe so that the board was visible for everyone). This environment adjusted participants to the realization of the optimistic scenario. Using the brainstorm method, the experts produced the ideas of future vision of rural schools that were written on the board and were taken photo of.

- The pessimistic scenario of future of rural schools was predicted in a room with bad lightning (the room was artificially darkened). There was performed dramatic music (the $1^{\text {st }}$ part of Beethoven $5^{\text {th }}$ symphony). The experts sat at the long desks that were moved together. The board was not visible for all experts; the ideas of the experts were entered in the minutes. The environment allowed the experts to be disposed to pessimistic vision of future of rural schools. The brainstorm method was also used here and the ideas were written on the board and were taken photo of.

- The realistic scenario of future of rural schools. After two previous stages, when completely different prognoses were expressed, the realistic vision of future of rural schools had to be predicted. There were available technical aids in the room, the material about the work of teachers, students and their parents of school and outdoor activities was offered. The classroom helped participants to be in the mood of reality of rural schools, pointing out their potential of sustainability and competitiveness with urban schools.

What is more, the form of cross-school mentoring and methodology of Walt Disney's method were approbated in the research of associated professor Irena Katane, Latvia University of Agriculture (Katane, 2005) that took place in Jaunjelgavas Secondary School in 2004.

To start with, the diversity and concurrence are seen in the thoughts of experts in the optimistic scenario that were stated in the seminars of 2004 and 2011. The concurrence of optimistic scenario can be ascribed to: 1) the school that has got some centers (for instance, adults' educational center, schools' informative center etc.); 2) the formal and non-formal education and vast offer of out-of-school activities, 3) the opening of different departments at school, for instance, musical, arts, sports, design and technology, foreign languages etc.; 4) the school's transport that is foreseen for inner necessities of the school; 5) a wide cooperation network (cooperation with hospital workers (for children with mental and physical derangements) as well as cooperation with nongovernmental organizations in Latvia and abroad); 6) modern equipment of the school; 7) vast audiences - from 
SOCIETY, INTEGRATION, EDUCATION. Proceedings of the International Scientifical Conference May 25th-26th, 2012, Volume I, Rēzeknes Augstskola, RA Izdevniecība, 2012,

preschool age pupil to the whole community society; 8) a high number of pupils at school.

The experts of 2004 seminar mostly thought about the rural school that could be accessible and opened to everyone and everything (changes, innovations) that could approbate and evaluate every innovation that enters the educational environment of rural schools, that would be democratically and humanistically oriented, taking into account pupils, who are taught according to individual programs, that would be an opened learning organization that is competitive. Right now modern, viable rural schools have already become learning organizations and they are democratic and opened to whole rural community.

The optimistic scenario of 2011 has innovative and diverse ideas that are connected with the offer of rural schools: 1) practices of many specialists psychologist, speech therapist, psychiatrist, interpreter, notary, instructor who teaches pupils how to drive etc.; 2)the organization of summer camps, where children teach parents and parents teach children many things; specialized summer camps, for instance, art or language camps; 3 ) the establishment of firms of pupils by the school (agriculture, craft, workshop etc.), where pupils can become acquainted with economy and entrepreneurship bases, and schools will get real products; 4) the foundation of swimming pool, skating-rink, carting trace and relaxation room for teachers in the school, mini zoo, which is taken care of by children, and children learn how to be compassionate and responsible; 5) the foundation of hostel or boarding-school by the school, taking into account that pupils live far away from schools and they have to cover long distances.

The thoughts of the experts of seminars of 2004 and 2011, working out the pessimistic scenario, were different and as well as matched in certain aspects. The concurrence of the pessimistic scenario is seen in such aspects: 1)the deterioration/crisis of demographical situation - low number of pupils in all country as well as at rural schools; 2)the change of the status of schools; 3 )the change of the cultural environment in the connection with the closure of rural schools; 4)the unfavourable social, economical situation of development of rural schools - high rate of unemployment in the district, low financial means of half of the parents, depression in the country, left houses and land, the lack of pedagogues due to the salary; 5)the closure of schools in the result of which inhabitants leave country and migrate to towns, the building of the school is privatized and there is opened an entertainment center or school stands empty or school stays as a museum for the rural community at best.

But some differences are seen in the pessimistic scenario of 2011 in comparison with 2004, for example: 1) the optimization process of schools, that is connected with school joining to another rural school as a branch office; 2) the insufficient finance for functioning of the rural school; 3) aspects of educational process - multi-graded classes, an incomplete cooperation of teachers with parents, insufficient achievements of some pupils; 4) there is also a possibility about guest 
SOCIETY, INTEGRATION, EDUCATION. Proceedings of the International Scientifical Conference May 25th-26th, 2012, Volume I, Rēzeknes Augstskola, RA Izdevniecība, 2012,

workers who will come to Latvia and will be housed at rural schools that are abandoned.

What is more, some aspects of the pessimistic scenario of 2004 have already become a reality, namely: 1) the reinforcement of expression of social deprivation of rural society (alcohol, social apathy, irresponsibility, lack of motivation, firstly, in the spheres of education, value orientation and attitude system etc.); 2) the transportation of children to the town and to distant places of the country that is troubled by bad conditions of roads and technical conditions of municipality transport; 3) the disarrangement and regress of rural infrastructure - uncultivated fields, left homes or even districts, development regress of production and national economy.

There is the concurrence of opinions of experts of the realistic scenario of 2004 and 2011 in such aspects: 1) the participation in local and European Union projects, for example, Eco school; 2) the education service and information for parents about the school life (a seminar, school's brochures "An Informative Edition" etc.); 3) the consolidation of material base, for instance, building of a sport hall (resolution of leisure time spending opportunities of young people and grownups); 4) the search of co-financing, for instance, projects, voluntary work, an involvement of European funds; 5) the cooperation with pupils' families (for example, courses, seminars, practical lessons that are organized for parents).

The realistic scenario of 2004 is already carried out in such points, for instance, 1) the awareness and acquisition of cultural historical values; 2) the usage of modern technology; 3)a wide offer of interest related education; 4) a school determines its activity priorities, is aware of its role in the conservation of educational environment; 5) searches for working niche, specificity, that could raise school on the level of a district; 6) the maintenance of psychological and personality contributing environment of development; 7) respect of main principles of human pedagogy.

There are still some aspects that were partly realized in the realistic scenario of 2004: 1) an output of alternative programs; 2) maximal parents' involvement in school; 3) the adults education is carried out on the existing base; 4) an acquisition opportunities of management and business for everyone int.al. teachers, etc.

The realistic scenario of 2011 has got both positive and negative features. The positive side of the realistic scenario includes: 1) the work of school's documentation in e-environment and e-class (www.e-klase.lv); 2) the extended learning specialization (sport, foreign languages, e-twinning, e-skills); 3) the offer of different educational programs, for instance, preschool educational program, adults' educational program in the context of lifelong learning, vocational programs of education; 4) the guarantee of good technical equipment; 5) an individual approach to every student; 6) the safe and favourable learning environment; 7) the involvement of parents into school life (establishment of nongovernmental organizations, clubs); the school is transformed into further education or interest related education center, where is possible to obtain skills in wood-processing, 
SOCIETY, INTEGRATION, EDUCATION. Proceedings of the International Scientifical Conference May 25th-26th, 2012, Volume I, Rēzeknes Augstskola, RA Izdevniecība, 2012,

painting of silk fabric, the place of summer camps, sport club, offer premises, for instance, gym; 8) the involvement of society into management of education; 9) less of bureaucracy; 10) prolonged days' groups etc. The negative side of the realistic scenario is connected with the low number of pupils and teachers, the weak material base of rural schools and old technologies.

Viewing the future vision of the school in the project Latvia 2030 Strategies of Sustainable Development of Latvia (Latvija $2030 \ldots$, 2009) in the chapter Change of Paradigm in Education is evaluated as social network center that is characterized from four aspects.

- The involvement of parents in the learning process. Teachers and school leaders should create closer bounds with parents of pupils. Several methods can be used - meetings, special occasions, courses for parents, or parents' room at school etc.

- Confrere working groups. To develop cooperation skills of pupils, everywhere else in the world are used peers' group methods, where pupils have to do different tasks not individually but together with classmates or with other pupils, parents, relatives or representatives from local community.

- Voluntary mentor programs. In the framework of these programs adults without any special pedagogical education can apply at schools as voluntary mentors or advisors and help children in the afternoons or evenings with homework or revision. Especially pensioners can be involved in these programs in such way diminishing the social isolation of them and strengthening connections between generations.

- Accessible networks of social service and support. There should be promoted social service, help and support events for different society groups, especially elder people, children and their parents. The activity of nongovernmental organizations, charity and social enterprises should be actively enabled and new working methods should be promoted, for instance, informative and consultative services in the digital environment with the emphasis on the social and digital networks. Municipality social service already functions as social network centers, for example, youngsters' day center and care center for elder people. For instance, the functions of social network centers carry out schools, churches and libraries in Scandinavia.

Secondly, the participants of cross-school mentoring seminars as inner experts worked on the study of prestige and success of rural schools.

The term school prestige is connected with importance and authority of schools, as well as pride and high evaluation in the society. Furthermore, it includes widely recognized respect and delight that are grounded on quality and achievement (Katane, Laizane, 2009).

In the organized cross-school mentoring seminars The Fluctuation of Educational Environment of Rural Schools in Latvia and Abroad in the 21st Century experts worked in groups, had discussions and kept down the minutes of 
SOCIETY, INTEGRATION, EDUCATION. Proceedings of the International Scientifical Conference May 25th-26th, 2012, Volume I, Rēzeknes Augstskola, RA Izdevniecība, 2012,

main ideas of participants. The experts of rural schools during seminars pointed out that there were many diverse influencing factors of prestige both on local (within the framework of rural community) and state's scale. As a result of summarization, analysis and evaluation of data (that was obtained from the minutes of the groups) all these influencing factors of prestige of rural schools were grouped into two groups: 1) representing factors of contexts (components) of school environment; 2) indicators of specificity of educational environment as prestige influencing factors.

The prestige of Latvian rural schools contains the representing factors of contexts (components) of school environment, for instance: 1) the improvement of physical base: the construction of fireplace hall for small events both for children and adults, etc.; 2) the factors of cultural environment: the conservation of culturally historical heritage, school is opened to everything new and creative; the association of cultural history at school, etc.; 3) the factors of social environment: cooperation with parents, families and support in awareness of family social conditions, etc.

The prestige of Latvian rural schools involves characteristic indicators of specificity of educational environment as prestige influencing factors, for example: 1) the ability to develop accordingly to requirements and individual approach; 2) the development and improvement of pedagogical proficiency; 3) the notice, development and presentation of talent and abilities of pupils; 4) the personal interest of pedagogues in the existence of school and maintenance of prestige, self-denial, the involvement of families, personal transport and time in the work; 5) the unchangeable staff, less pedagogues who combine jobs; 6)the pedagogues are far and wide educated, are connected with pupils all 9 years (basic education);

7) the qualitative education is offered children, who are diagnosed mental derangements of development, only in the specially arranged and equipped educational establishments - special rural schools; 8) the participation in various projects: Comenius, e-twinning projects, ERAF (European Regional Structural Fund) projects (for instance, "Cooperation Network of Cross-border Craft as the Facilitator of Attraction of Latvian Lithuanian Cross-border", as a result a woodprocessing workshop was renovated and it was reorganized into craft center); 9) the initiative program of community, for instance, "Together with Family to School" established the support center of housekeeping skills; 10) the organization of summer camps, for example "The School of Creative Talents"; 11) the participation in many competitions like the environmental educational program "Find out the Forest" organized by Latvian State Forests (the diploma of the expert), the competition of collecting waste paper "You can Save" (gratefulness for contribution in the conservation of clean environment); 12) the realization of spiritual educational program at school, for example, old-believer's; 13) the organization of events with children and families with involvement of well-known people from Latvian society; 14) the close cooperation with state and nongovernmental organizations, for instance, agro firm Turiba, SIA Preilu hospital etc. partners; 15) 
SOCIETY, INTEGRATION, EDUCATION. Proceedings of the International Scientifical Conference May 25th-26th, 2012, Volume I, Rēzeknes Augstskola, RA Izdevniecība, 2012,

the school's support for pupils, for example, partly paid lunch for pupils; refund of transport expenditure; a hostel, a boarding school, a fitness hall, schools' cooperation projects etc.; 16) the positive incentives of school, for example, rewards for pupils with good results in learning, diplomas, paid excursions, money awards, grants for secondary school's pupils; 17) the accessibility of education for every age group because there is a consulting place of extramural courses; 18) the pride of the school, high identity sense of every worker, pupil, etc.

The findings on prestige conclude that Latvian rural schools work very hard in order to perceive high results and reputation in the local society. Nowadays rural schools offer opened educational environment not only for pupils as well as the local community because every rural school has got its educational and cultural offer of events that makes it different from each other.

\section{Conclusions}

The results of cross-school mentoring seminars reveal that:

- The optimistic scenario of rural school was foreseen, grounding on the concept of effective school of future, that the educational environment is opened for the whole community, for everything new and innovative. School's financial, emotionally psychological, didactical and social environments maximally correspond to the requirements not only of rural inhabitants, but also to the requirements of the whole society. Negative, influential outer and inner factors of activity of schools are not taken into account in this vision that can hinder the sustainability of them. On the contrary, experts' attention was focused on opportunities that can be offered by favourable situation in the education sphere. At the same time it shows the ideal vision of the school in the future that was formed, intensifying the meaning of inner potential of rural school.

- The pessimistic scenario was predicted taking into account only negative, from school independent outer factors of environment, that nowadays in general negatively influence (endanger) rural school and sustainability of rural cultural environment, as well as the weakness of rural school - inner, from school dependent factors, that define inability to bear the competition among them and urban schools, ignoring real development opportunities of schools in the countryside, as well as inner resources of these schools as potential of development. The central conclusion of the pessimistic scenario is the change of the status of the school and liquidation, pointing out the destructive consequences in the rural environment in general.

- Inner and outer factors have been balanced in the realistic visions of future of rural schools that have "+" and "-" characters. Experts, carrying out this prognosis, were grounding on nowadays best work of rural schools and really existing educational models as real examples of nowadays practices of rural schools.

- The observations done during the forming experiment show that there is a great meaning of environment and chosen methodology. The working environment 
SOCIETY, INTEGRATION, EDUCATION. Proceedings of the International Scientifical Conference May 25th-26th, 2012, Volume I, Rēzeknes Augstskola, RA Izdevniecība, 2012,

pp. $107-116$

also determined the work of the experts (the premises, light, what was heard and seen). That is why it can be concluded that educational models of rural schools to great extent dependent on specific character of rural schools as well as on the whole educational environment of state, on dominating educational and pedagogical paradigms in rural schools.

- The comparison of expert prognoses of 2004 and 2011 shows that many of them has already fulfilled, for instance, the change of the school status, liquidation, low number of pupils and teachers and prognoses connected with the real future of Latvian rural schools - the education of guest workers in rural schools because the number of inhabitants of Latvia decreases and especially in the country.

The influencing factors of prestige of rural schools are divided into two main groups: 1) representing factors of contexts (components) of school environment; 2) indicators of specificity of educational environment as prestige influencing factors.

\section{Bibliography}

1. Katane, I., Laizāne, A. (2009). Skolas prestīžu nosakošie faktori skolēnu vecāku vērtējumā. (The Definable Factors of the School's Prestige in the Evaluation of Pupils' Parents.) Starptautiskās zinātniskās konferences materiāli Sabiedrība, integrācija, izglītība, 2009.gada 27.-28.februāris, Rēzekne, 350.-359.lpp. (in Latvian)

2. Katane, I. (2005). Lauku skolas kā izglīīibas vides izvērtēšanas modelis. Promocijas darbs pedagogijas zinātnes skolas pedagoǵijas apakšnozarē. (The Evaluation Model of the Rural School as Educational Environment. Doctoral dissertation in the sub-branch of School's Pedagogy). Jelgava, Daugavpils, LLU TF IMI; DU, 195 lpp. (in Latvian)

3. Latvija 2030 Latvijas ilgtspējīgas attīstības stratēgija. Projekts. (2009). Reğionālās attīstības un pašvaldību lietu ministrija. Retrieved January 5, 2011 http://www.latvija2030.1v/upload/latvija2030_lv.pdf

4. Online Business Dictionary. Retrieved December 26, 2011 http://www.businessdictionary.com/definition/organization.html

5. O'Connor J., Seymour J. (1994). Training with NLP. London. Thorsons. Briede B., Pēks L. (1998). Pedagoǵiskā vide. Zinātniskā konference Mājturības pedagoğiskās aktualitātes. Raksti. Jelgava, LLU, 87. - 92.lpp.

6. Strategic Leadership and Decision Making. (s.a.). Section Strategic Vision. National $\begin{array}{llll}\text { Defence } \quad \text { University. } & \text { Retrieved } & \text { December }\end{array}$ http://www.au.af.mil/au/awc/awcgate/ndu/strat-ldr-dm/pt4ch18.html,

7. Woods, Ph. A. (2005). Democratic Leadership in Education. London: SAGE, p.167

Autores veikto pētījumu atbalstīja Eiropas Sociālā fonda projekts Atbalsts LLU doktora studiju ìstenošanai.

Anna Laizāne Latvia University of Agriculture,

Institute of Education and Home Economics,

J.Čakstes bulv. 5, Jelgava, LV 3001, Latvia

E-mail: anna_laizane@inbox.lv

Phone: +37122145337 